REVIEW

\title{
CAUSES OF MATERNAL MORTALITY IN ETHIOPIA: A SIGNIFICANT DECLINE IN ABORTION RELATED DEATH
}

\author{
Yifru Berhan", Asres Berhan ${ }^{2}$
}

\begin{abstract}
BACKGROUND: Although the common direct obstetric causes of maternal mortality are known from the literature, the contribution of each cause and the change in trend over decades is unknown in Ethiopia. The objective of this review was to assess the trend of proportion of maternal mortality due to the common direct causes.

METHODS: This systematic review was done on eighteen health facility based maternal mortality studies conducted between 1980 and 2012 in Ethiopia. Emphasis was given to the proportion of maternal mortality due to direct causes and their case fatality rates.

RESULTS: The summary of the findings has shown that the top four causes of maternal mortality in the year 1980-1999 were abortion related complications (31\%), obstructed labor/uterine rupture (29\%), sepsis/infection (21\%) and hemorrhage (12\%). In the last decade, however, the top four causes of maternal mortality were obstructed labor/uterine rupture (36\%), hemorrhage (22\%), hypertensive disorders of pregnancy (19\%) and sepsis/infection (13\%).

CONCLUSION: Abortion and infection related maternal deaths have declined significantly in the last decade. Obstructed labor continues to be the major cause of maternal deaths; maternal deaths due to hypertensive disorders and hemorrhage showed an increasing trend. The findings in this review were somehow comparable with the WHO analysis for Africa in the same period with the exception of obstructed labor.

KEY WORDS: abortion, cause, Ethiopia, hemorrhage, maternal mortality, obstructed labor, infection, systematic review
\end{abstract}

DOI: http://dx.doi.org/10.4314/ejhs.v24i1.3S

\section{INTRODUCTION}

Maternal death refers to the death of women during pregnancy, childbirth and the first 42 days of the postpartum period from any cause related to or aggravated by pregnancy (1). Globally, approximately half a million maternal deaths occur every year (2). Specifically in the low income countries, maternal deaths due to pregnancy and childbirth-related complications are the major causes of death of women in the reproductive age group (3).
Traditionally, the causes of maternal mortality have been classified as direct and indirect, each contributing to about $70 \%-80 \%$ and $20 \%-30 \%$ of the total maternal deaths, respectively (4-7). It is also known that the major causes of maternal deaths are similar across low income countries, often obstetric in origin, and generally follow obstructed labor with or without rupture, hypertensive disorders (mainly severe preeclampsia and eclampsia), infection and hemorrhage (mainly placenta previa/abruption, urine rapture and postpartum hemorrhage) (8).

\footnotetext{
${ }^{1}$ Hawassa University, College of Medicine and Health Sciences, Department of Gynecology-Obstetrics

${ }^{2}$ Hawassa University, College of Medicine and Health Sciences, Department of Pharmacology

Corresponding Author: Yifru Berhan, Email: yifrub@gmail.com
} 
The majority of these fatal obstetric complications occur during labor and immediately after birth. As a result, in the low income countries like Ethiopia, more than three-quarters of maternal deaths due to the direct obstetric causes occur during and after birth $(4,5,9,10)$.

What is not exactly known in Ethiopia is the contribution of each of these common causes to the overall maternal mortality. Furthermore, little is known about the trend of maternal mortality due to the direct obstetric causes. Unlike the previous review which included only hospital based studies (before 2008) to estimate the causes of maternal mortality $(11,12)$, the strength of this review is that it has also included recent hospital based and two national representative studies.

The objective of this review was to assess the trend of proportion of maternal mortality due to the top five direct causes (obstructed labor with or without uterine rupture, hypertensive disorders, infection, abortion and hemorrhage) in about 30 years period using available health facilities-based data. Literature search has not shown similar study in this country.

\section{METHODS}

\section{Search strategy}

The literature search strategy used for this systematic review was focusing on electronically accessible studies in different data bases. The majority of the studies included were retrieved from local journals, MEDLINE and PUBMED. During literature search, the following search terms were used in alternate combination: causes of maternal mortality, the case fatality rate, obstructed labor, uterine rupture, hypertensive disorders of pregnancy, preeclampsia, eclampsia, abortion, hemorrhage, antepartum hemorrhage, postpartum hemorrhage, infection, sepsis, Ethiopia and Africa.

\section{Study selection and data abstraction}

From the studies included, the following information was abstracted: name of authors, study period, study design, study location, major conclusion drawn with regard to causes of maternal deaths, the number and proportion of maternal deaths, the number of maternal deaths and the case fatality rate of specific causes. For the methodological validity, study selection was done by two authors (YB and $\mathrm{AB}$ ) independently in two phases: 1) by reviewing the titles and abstracts of the retrieved literature, and 2) by reviewing the whole document which were initially categorized as "eligible for further screening".

\section{Inclusion criteria}

The selected studies were cross sectional and cohort by design. The focus of interest for this review was causes of maternal mortality during the study period. Health facility- based studies that addressed causes of maternal mortality as proportion or case fatality rate and published in either electronically accessible or local journals between 1980 and 2012 in Ethiopia were included. In this review, hypertensive disorder of pregnancy means preeclampsia or eclampsia. Maternal deaths due to hemorrhage include both antepartum and postpartum hemorrhage. Similarly, maternal deaths due to 1) obstructed labor and uterine rupture, and 2) infection and sepsis were reviewed together.

\section{Data synthesis}

To estimate the proportion of maternal mortality due to direct obstetric causes, the total number of (actual values) maternal deaths in each study was added as denominator and similarly, the actual number of maternal deaths due to a specific cause in each study was added as numerator. Data were summarized in the form of table and bar graphs. The direct causes of maternal mortality were categorized as before and after year 2000 .

Although there were some potential overlaps in terms of categorizing the possible causes of maternal mortality (for instance, some maternal deaths attributed to puerperal sepsis may be primarily due to obstructed labor; and some maternal deaths attributed to infections might be due to unsafe abortion), the categories put in the primary studies were not manipulated.

\section{RESULTS}

This review includes 19 health facility-based studies from Ethiopia, which were reported between 1980 and 2012 (13-31). Among the included studies, 15 were done in 1-3 hospitals (13-23, 27, 29, 30), from 8-15 health facilities (8, $29)$ and two $(25,26)$ from representative large scale national studies. 
The available health facility studies in Ethiopia on causes of maternal deaths were limited to a few hospitals till 2007-2008 when the national representative and comprehensive assessment for emergency obstetric and newborn care was done in 797 health facilities (26). It included 45,870 women with complications; of which, 685 (1.5\%) were maternal deaths. Another national representative study from 344 public and private health facilities in the year 2007-2008 by including 57,964 women with abortion related maternal mortality and morbidity gave much weight to estimate the abortion related maternal mortality (25).

Among single hospital based studies, the report by Gaym A (16) for the period 1990-1999 and by Kelly J et al (20) for the period 1987-2008 included large case series data. The majority of the studies included from Ethiopia were retrospective chart reviews. The first report on causes of maternal mortality was from Tikur Anbesa Hospital in 1988 by Yoseph S et al (13). Table 1 summarizes the studies included in this review.

Table 1: General characteristics of the included studies (15-35)

\begin{tabular}{|c|c|c|c|c|c|}
\hline Authors & $\begin{array}{l}\text { Study } \\
\text { period }\end{array}$ & Study site & Study design & $\begin{array}{l}\text { Areas of } \\
\text { interest for } \\
\text { this review } \\
\end{array}$ & $\begin{array}{l}\text { Major conclusion of interest } \\
\text { for this review }\end{array}$ \\
\hline $\begin{array}{l}\text { Yoseph } S \\
\text { et al (15) }\end{array}$ & $\begin{array}{l}1980- \\
1985\end{array}$ & $\begin{array}{l}\text { Tikur Anbesa } \\
\text { Hospital, } \\
\text { Central }\end{array}$ & $\begin{array}{l}\text { Retrospective } \\
\text { cross sectional }\end{array}$ & $\begin{array}{l}\text { Causes of } \\
\text { maternal } \\
\text { mortality }\end{array}$ & $\begin{array}{l}\text { Unsafe abortion, infection and } \\
\text { obstructed labor were the major } \\
\text { causes of maternal mortality. }\end{array}$ \\
\hline $\begin{array}{l}\text { Yusuf L et } \\
\text { al (16) }\end{array}$ & $\begin{array}{l}1988- \\
1993\end{array}$ & $\begin{array}{l}\text { Gondar } \\
\text { Hospital, } \\
\text { Northwest } \\
\text { Ethiopia }\end{array}$ & Cross sectional & $\begin{array}{l}\text { Abortion } \\
\text { related } \\
\text { maternal } \\
\text { mortality }\end{array}$ & $\begin{array}{l}\text { Abortion related maternal } \\
\text { mortality was relatively low. }\end{array}$ \\
\hline $\begin{array}{l}\text { Alli } \\
(17)\end{array}$ & $\begin{array}{l}\text { Oct } \\
1991- \\
\text { Dec } \\
1992 \\
\end{array}$ & $\begin{array}{l}\text { Jimma } \\
\text { Hospital, } \\
\text { Southwest } \\
\text { Ethiopia }\end{array}$ & $\begin{array}{l}\text { Retrospective } \\
\text { cross sectional }\end{array}$ & $\begin{array}{l}\text { Maternal } \\
\text { deaths and } \\
\text { causes }\end{array}$ & $\begin{array}{l}\text { Unsafe abortion, obstructed } \\
\text { labor and hemorrhage were the } \\
\text { leading causes of maternal } \\
\text { deaths. }\end{array}$ \\
\hline $\begin{array}{l}\text { Gaym A et } \\
\text { al (18) }\end{array}$ & $\begin{array}{l}1990- \\
1998\end{array}$ & $\begin{array}{l}\text { Jimma } \\
\text { Hospital, } \\
\text { Southwest } \\
\text { Ethiopia }\end{array}$ & $\begin{array}{l}\text { Retrospective } \\
\text { cross sectional }\end{array}$ & $\begin{array}{l}\text { Causes of } \\
\text { maternal } \\
\text { mortality }\end{array}$ & $\begin{array}{l}\text { Obstructed labor, unsafe } \\
\text { abortion and puerperal sepsis } \\
\text { were the leading causes of } \\
\text { maternal deaths }\end{array}$ \\
\hline $\begin{array}{l}\text { Abate M } \\
\text { et al (19) }\end{array}$ & $\begin{array}{l}\text { Oct } \\
1994- \\
\text { Sept } \\
1999\end{array}$ & $\begin{array}{l}\text { Tikur Anbessa } \\
\text { and St. Paul's } \\
\text { Hospitals, } \\
\text { Central }\end{array}$ & $\begin{array}{l}\text { Retrospective } \\
\text { cross sectional }\end{array}$ & $\begin{array}{l}\text { Eclampsia } \\
\text { related } \\
\text { maternal } \\
\text { mortality }\end{array}$ & $\begin{array}{l}\text { Eclampsia was associated with } \\
\text { high maternal mortality. }\end{array}$ \\
\hline $\begin{array}{l}\text { Gessessew } \\
\text { A et al } \\
(20)\end{array}$ & $\begin{array}{l}1993- \\
2001\end{array}$ & $\begin{array}{l}\text { Adigrat } \\
\text { Hospital, } \\
\text { North Ethiopia }\end{array}$ & $\begin{array}{l}\text { Retrospective } \\
\text { cross sectional }\end{array}$ & $\begin{array}{l}\text { Obstructed } \\
\text { labor related } \\
\text { maternal } \\
\text { mortality }\end{array}$ & $\begin{array}{l}\text { Incidence and complications of } \\
\text { obstructed labor were high. }\end{array}$ \\
\hline $\begin{array}{l}\text { Berihun E } \\
\text { et al (21) }\end{array}$ & $\begin{array}{l}\text { Oct } \\
1995- \\
\text { Sept } \\
2004\end{array}$ & $\begin{array}{l}\text { Tikur Anbesa } \\
\text { Hospital, } \\
\text { Central }\end{array}$ & $\begin{array}{l}\text { Retrospective } \\
\text { cross sectional }\end{array}$ & $\begin{array}{l}\text { Eclampsia } \\
\text { related } \\
\text { maternal } \\
\text { mortality }\end{array}$ & $\begin{array}{l}\text { More than a quarter of } \\
\text { eclamptic mothers died. }\end{array}$ \\
\hline $\begin{array}{l}\text { Kelly J et } \\
\text { al (22) }\end{array}$ & $\begin{array}{l}1987- \\
2008\end{array}$ & $\begin{array}{l}\text { Atat Hospital, } \\
\text { Central South } \\
\text { Ethiopia }\end{array}$ & $\begin{array}{l}\text { Retrospective } \\
\text { cohort }\end{array}$ & $\begin{array}{l}\text { Maternal } \\
\text { mortality } \\
\text { and causes }\end{array}$ & $\begin{array}{l}\text { Obstructed labor, hemorrhage, } \\
\text { hypertensive diseases and } \\
\text { malaria were the most common } \\
\text { causes of maternal deaths. }\end{array}$ \\
\hline
\end{tabular}




\begin{tabular}{|c|c|c|c|c|c|}
\hline $\begin{array}{l}\text { Berhan Y } \\
\text { et al (23) }\end{array}$ & $\begin{array}{l}2001- \\
2002\end{array}$ & $\begin{array}{l}\text { Tikur Anbessa } \\
\text { Hospital, } \\
\text { Central }\end{array}$ & $\begin{array}{l}\text { Retrospective } \\
\text { cross sectional }\end{array}$ & $\begin{array}{l}\text { Causes of } \\
\text { maternal } \\
\text { mortality }\end{array}$ & $\begin{array}{l}\text { Unsafe abortion, eclampsia and } \\
\text { obstructed labor were the top } \\
\text { three causes of maternal } \\
\text { deaths. }\end{array}$ \\
\hline $\begin{array}{l}\text { Garomsa } \\
\mathrm{H} \text { et al } \\
(24)\end{array}$ & $\begin{array}{l}2001- \\
2005\end{array}$ & $\begin{array}{l}\text { Ambo } \\
\text { Hospital, } \\
\text { Central West } \\
\text { Ethiopia }\end{array}$ & $\begin{array}{l}\text { Retrospective } \\
\text { cross sectional }\end{array}$ & $\begin{array}{l}\text { Maternal } \\
\text { deaths and } \\
\text { causes }\end{array}$ & 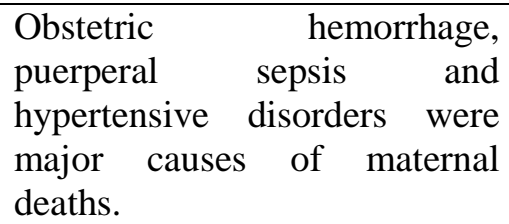 \\
\hline $\begin{array}{l}\text { Gessessew } \\
\text { A }(25)\end{array}$ & $\begin{array}{l}1993- \\
2003\end{array}$ & $\begin{array}{l}\text { Adigrat } \\
\text { Hospital, } \\
\text { North Ethiopia }\end{array}$ & $\begin{array}{l}\text { Retrospective } \\
\text { cross sectional }\end{array}$ & $\begin{array}{l}\text { Causes of } \\
\text { maternal } \\
\text { mortality }\end{array}$ & $\begin{array}{lrr}\begin{array}{l}\text { Maternal mortality due } \\
\text { obstructed }\end{array} \begin{array}{l}\text { labor } \\
\text { incomparably high. }\end{array} & \\
\text { was } \\
\end{array}$ \\
\hline $\begin{array}{l}\text { Negusse D } \\
\text { et al (26) }\end{array}$ & $\begin{array}{l}2002- \\
2006\end{array}$ & $\begin{array}{l}\text { Jima Hospital, } \\
\text { south west } \\
\text { Ethiopia }\end{array}$ & $\begin{array}{l}\text { Retrospective } \\
\text { cross sectional }\end{array}$ & $\begin{array}{l}\text { Causes of } \\
\text { maternal } \\
\text { mortality }\end{array}$ & $\begin{array}{l}\text { Obstructed labor, puerperal } \\
\text { sepsis and unsafe abortion } \\
\text { were major causes of maternal } \\
\text { deaths. }\end{array}$ \\
\hline $\begin{array}{l}\text { Gebreselas } \\
\text { sie } \mathrm{H} \text { et al } \\
(27)\end{array}$ & $\begin{array}{l}\text { Nov } \\
2007- \\
\text { March } \\
2008\end{array}$ & $\begin{array}{l}\text { Multiple health } \\
\text { facility, } \\
\text { National } \\
\text { representative }\end{array}$ & $\begin{array}{l}\text { Mixed method } \\
\text { (prospective \& } \\
\text { retrospective) }\end{array}$ & $\begin{array}{l}\text { Abortion } \\
\text { related } \\
\text { maternal } \\
\text { mortality }\end{array}$ & Maternal deaths were rare. \\
\hline $\begin{array}{l}\text { FMOH, } \\
\text { UNICEF, } \\
\text { UNFPA, } \\
\text { WHO, } \\
\text { AMDD } \\
(28)\end{array}$ & $\begin{array}{l}\text { Oct } \\
2008- \\
\text { Jan } \\
2009\end{array}$ & $\begin{array}{l}\text { Multiple } \\
\text { facility, } \\
\text { National } \\
\text { representative }\end{array}$ & $\begin{array}{l}\text { Chart review } \\
\text { for obstetric } \\
\text { complications } \\
\text { and maternal } \\
\text { deaths }\end{array}$ & $\begin{array}{l}\text { Causes of } \\
\text { maternal } \\
\text { mortality }\end{array}$ & $\begin{array}{l}\text { Obstructed labor, hemorrhage } \\
\text { and hypertensive diseases were } \\
\text { the major causes of maternal } \\
\text { deaths. }\end{array}$ \\
\hline FIGO (29) & $\begin{array}{l}2011- \\
2012 \\
\end{array}$ & $\begin{array}{l}\text { Multicenter } \\
\text { (Eight } \\
\text { hospitals) }\end{array}$ & $\begin{array}{l}\text { Prospective } \\
\text { cohort }\end{array}$ & $\begin{array}{l}\text { Causes of } \\
\text { maternal } \\
\text { mortality }\end{array}$ & $\begin{array}{l}\text { Preeclampsia/eclampsia was } \\
\text { the major cause of maternal } \\
\text { mortality. }\end{array}$ \\
\hline $\begin{array}{l}\text { Endeshaw } \\
\text { G et al } \\
(30)\end{array}$ & $\begin{array}{l}2008- \\
2012\end{array}$ & $\begin{array}{l}\text { Hawassa, } \\
\text { Yirgalem \& } \\
\text { Hosaena } \\
\text { hospitals }\end{array}$ & $\begin{array}{l}\text { Retrospective } \\
\text { cohort }\end{array}$ & $\begin{array}{l}\text { Maternal } \\
\text { mortality } \\
\text { due to } \\
\text { hypertension }\end{array}$ & $\begin{array}{l}\text { Maternal deaths were relatively } \\
\text { low. }\end{array}$ \\
\hline $\begin{array}{l}\text { Gessessew } \\
\text { A (31) }\end{array}$ & $\begin{array}{l}2002- \\
2004\end{array}$ & $\begin{array}{l}\text { Adigrat } \\
\text { Hospital, } \\
\text { North Ethiopia }\end{array}$ & $\begin{array}{l}\text { Prospective } \\
\text { cohort }\end{array}$ & $\begin{array}{l}\text { Abortion } \\
\text { related } \\
\text { maternal } \\
\text { mortality }\end{array}$ & Maternal deaths were rare. \\
\hline $\begin{array}{l}\text { Mekbib T } \\
\text { et al (32) }\end{array}$ & $\begin{array}{l}\text { June }- \\
\text { Dec } \\
2000\end{array}$ & $\begin{array}{l}\text { Multiple health } \\
\text { facility }\end{array}$ & Cross sectional & $\begin{array}{l}\text { Abortion } \\
\text { related } \\
\text { maternal } \\
\text { mortality }\end{array}$ & $\begin{array}{l}\text { The case fatality rate of } \\
\text { abortion procedures was high. }\end{array}$ \\
\hline $\begin{array}{l}\text { Ghidey et } \\
\text { al (33) }\end{array}$ & $\begin{array}{l}1985- \\
1989\end{array}$ & $\begin{array}{l}\text { Jimma } \\
\text { Hospital }\end{array}$ & $\begin{array}{l}\text { Retrospective } \\
\text { cross sectional }\end{array}$ & $\begin{array}{l}\text { Causes of } \\
\text { maternal } \\
\text { mortality }\end{array}$ & $\begin{array}{l}\text { Nearly } 50 \% \text { of the maternal } \\
\text { deaths were due to uterine } \\
\text { rupture }\end{array}$ \\
\hline
\end{tabular}


Figure 1 shows the proportion of abortion related maternal mortality in Ethiopia between 1980 and 2008. Although there were variations in sample size, geographical location, timing of report and the design among the studies, the trend line demonstrated that the gross estimate of maternal mortality due to abortion was decreasing. Particularly, the national representative study showed that among the total maternal deaths, the proportion of maternal mortality due to abortion related complications was about $6 \%$ in the late 2000s (26). Although the highest proportion of abortion related maternal mortality was reported from Jimma Hospital in the early 1990s (15), the sample size was not as large as the report by Gaym A from the same hospital for 1990-1999 (16). Similarly, the reports from Tikur Anbesa in the mid-1980s (13) and in the early 2000s (21) included relatively few cases series. The five studies $(16,20,22,24,26)$ with relatively large sample size were strong enough to conclude that abortion related maternal mortality in the included health facilities was in a declining trend in the last three decades.

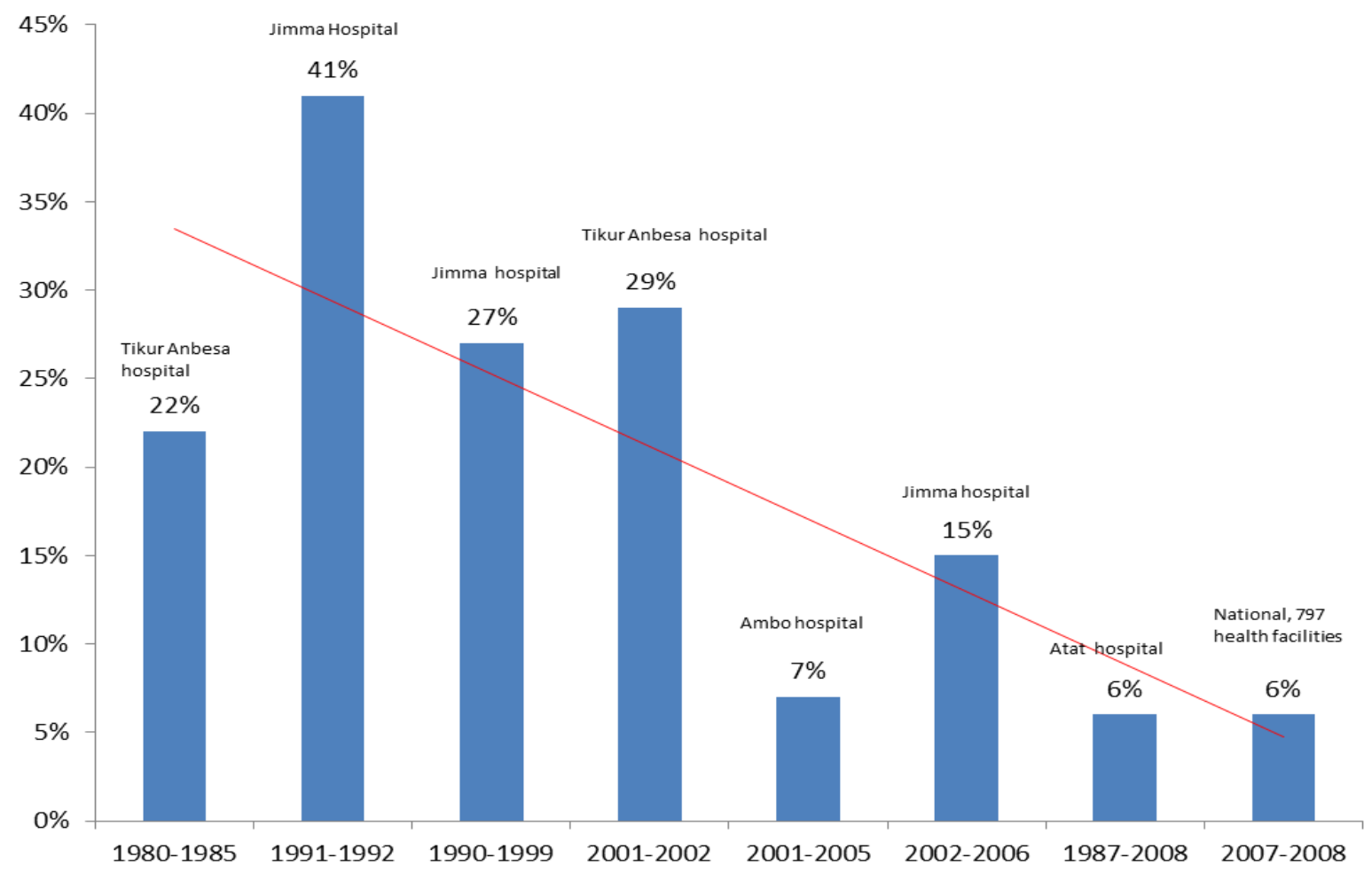

Figure 1: The proportion of maternal mortality due to abortion in Ethiopia between 1980 and 2008 (health facility based studies $)(15,17,18,22-24,26,28)$

Furthermore, as shown in Figure 2, the overall case fatality rate of abortion complication in another nationally representative study by Gebreselassie $\mathrm{H}$ et al was about $0.2 \%$ (95\% CI, $0.1-0.4 \%$ ) (25), which was lower by six-fold than another study report from 15 public hospitals in Ethiopia (1.2\%) (30). This study (25), however, showed that the case fatality rate of abortion in public hospitals was more than three-fold of the overall case fatality rate $(0.2 \%$ vs $0.63 \%)$. Nevertheless, it was not as high as the case fatality rate of abortion in the baseline assessment for emergency obstetric and newborn care (26), which was nearly 4-fold of the estimates made by Gebreselassie $\mathrm{H}$ et al for public hospitals $(0.6 \%$ vs $2.2 \%)$.

The case fatality rates of abortion reported from Gondar Hospital (14) about two decades ago and from Adigrat Hospital (23) about a decade ago were also among the lowest (about $0.3 \%$ each). The highest case fatality rates were reported from Jimma Hospital (15) and Tikur Anbesa Hospital (21) in the early 1990s and 2000s, respectively. 


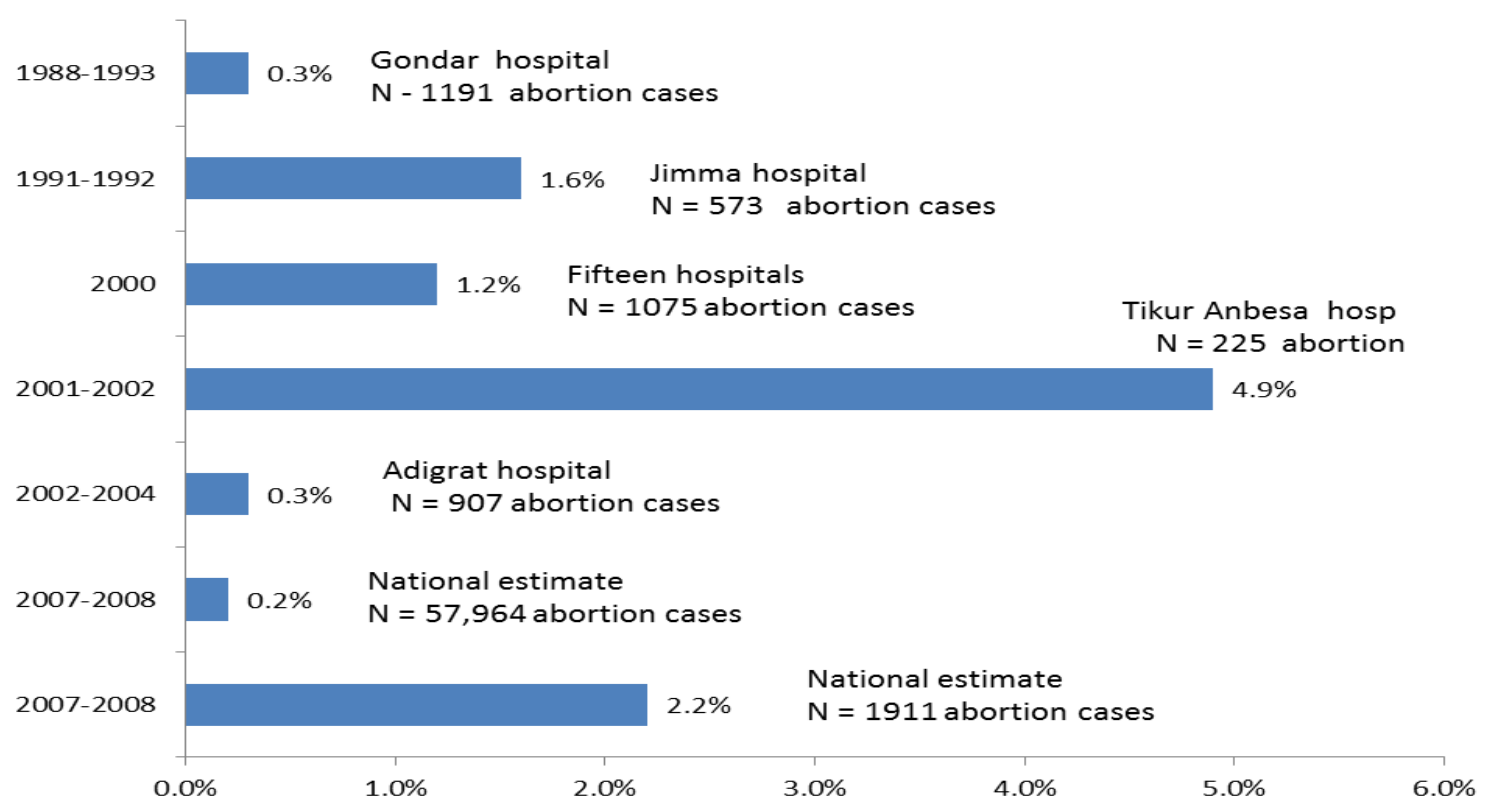

Figure 2: The case fatality rate of abortion in Ethiopia between 1988 and 2008 (health facility based studies) $(16,17,22,25,27,28,32)$

Figure 3 shows the proportion of maternal mortality due to obstructed labor or uterine rupture in different public hospitals between 1980 and 2012. The highest proportion of obstructed labor/uterine rupture related maternal deaths were reported from Jimma and Ambo hospitals in the 1980s-1990s $(15,16,29,31)$ and early 2000s (22,
24); about half to one-third of all maternal deaths during each study period were due to obstructed labor or uterine rupture. However, the national representative study (26) and FIGO estimates from eight public hospitals (27) showed a lower proportion of maternal deaths due to obstructed labor or uterine rupture.

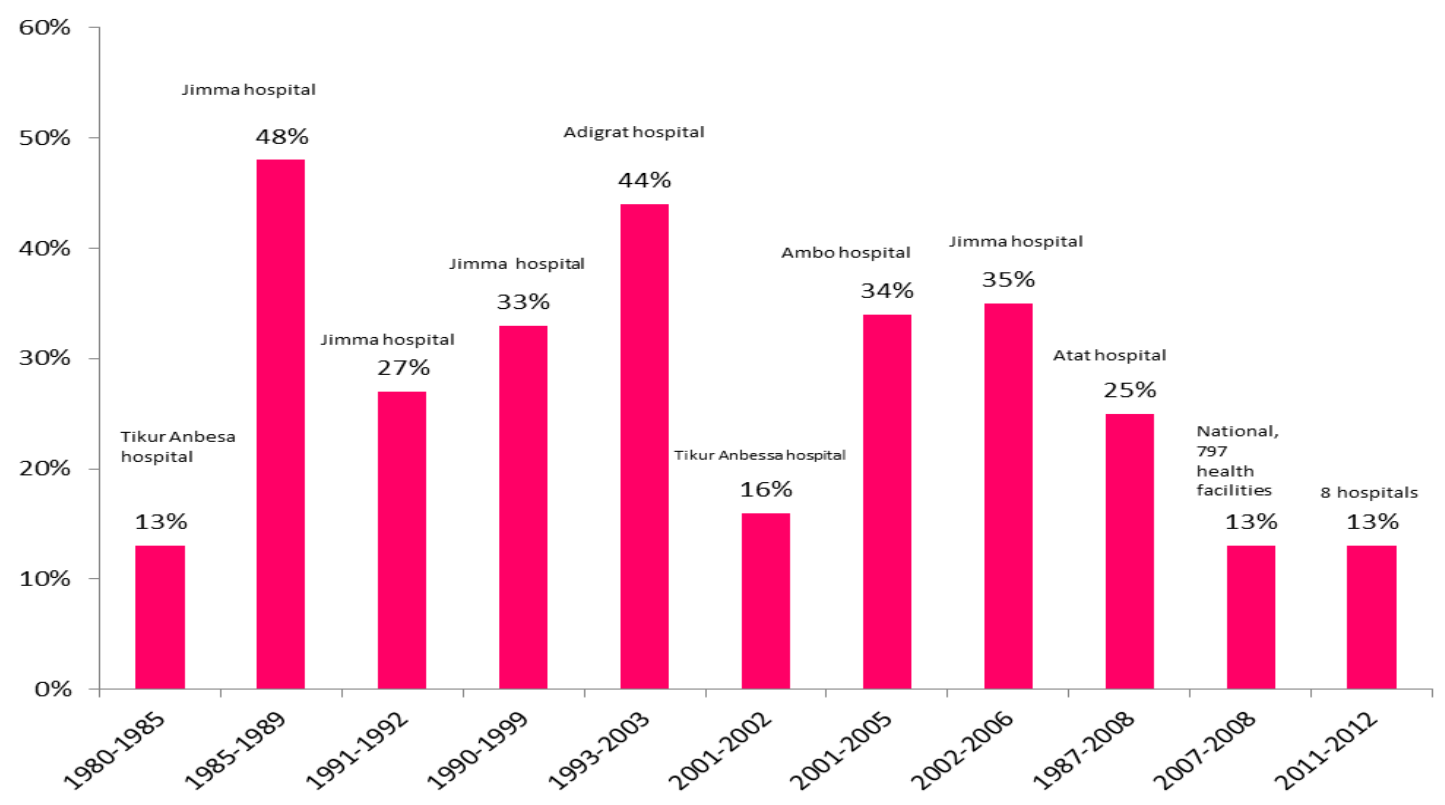

Figure 3: The proportion of maternal mortality due to obstructed labor/uterine rupture in Ethiopia between 1980 and 2012 (health facility based studies) (15, 17, 18, 22-24, 26, 28, 29, 31) 
The proportion of maternal mortality in Ethiopia due to hypertensive disorders between 1980 and 2012 is presented in Figure 4. Although the setup, design and timing vary among the included studies, an overall increasing trend of maternal deaths due to hypertensive disorders is observed.
The high proportion of maternal deaths due to hypertension in Tikur Anbesa Hospital (21\% of all maternal deaths) may not be strong evidence because of the small sample size ( 8 maternal deaths out of 22 eclamptic mothers or out of 38 total maternal deaths) (21).

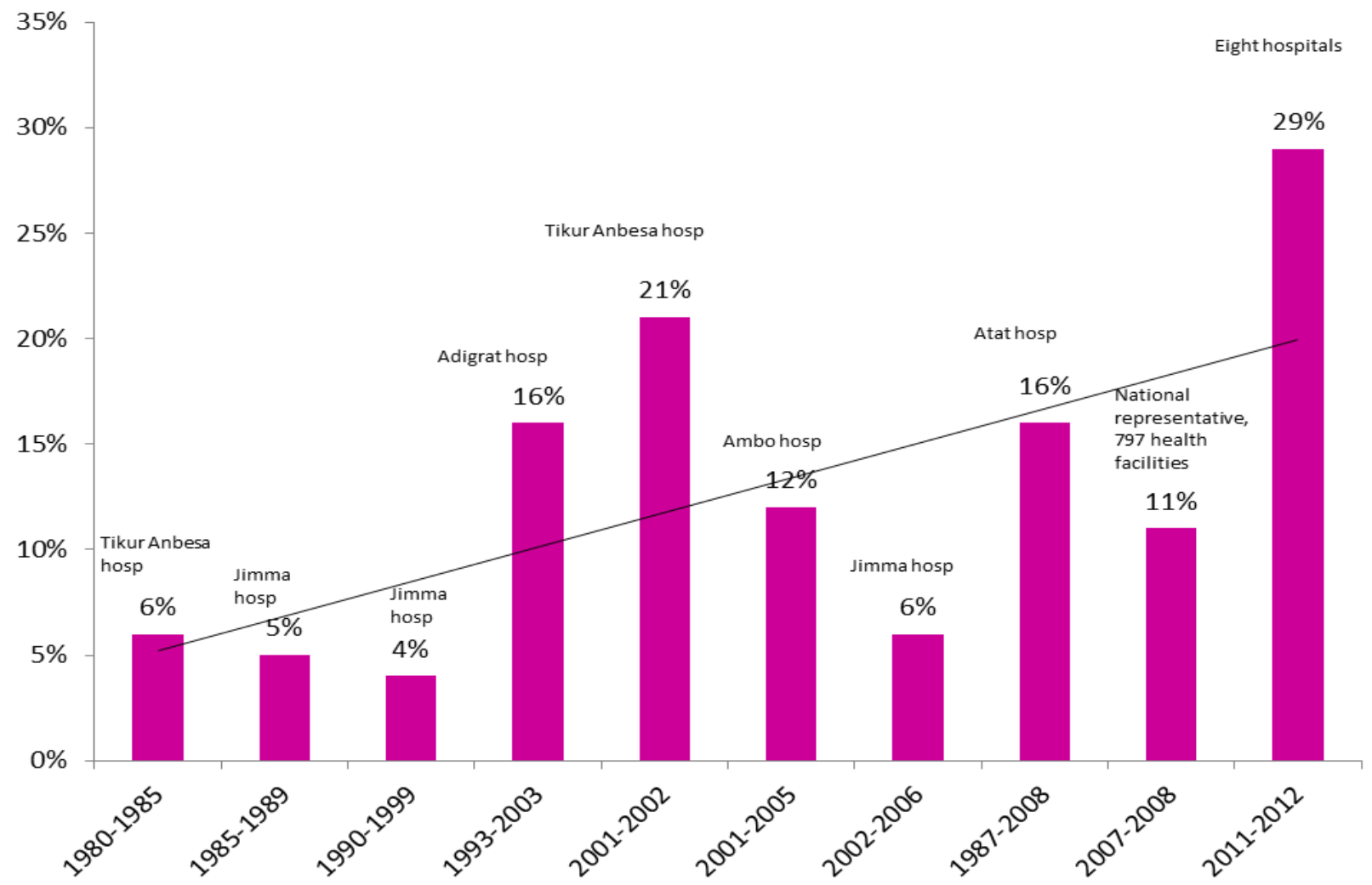

Figure 4: The proportion of maternal mortality due to hypertensive disorders in Ethiopia between 1980 \& 2012 (health facility based studies) $(15,18,22-24,26,28,29,31)$

Similarly, the FIGO report seems to have an influence for the increasing trend line. Above all, the national estimate (26) for hypertensive diseases related maternal mortality for the year 2007-2008 was $11 \%$, and might be taken as strong baseline evidence. The case fatality rates in the nationally representative study (26) and FIGO's study from eight hospitals (27) were the lowest ever reported in Ethiopia (Figure 5). 


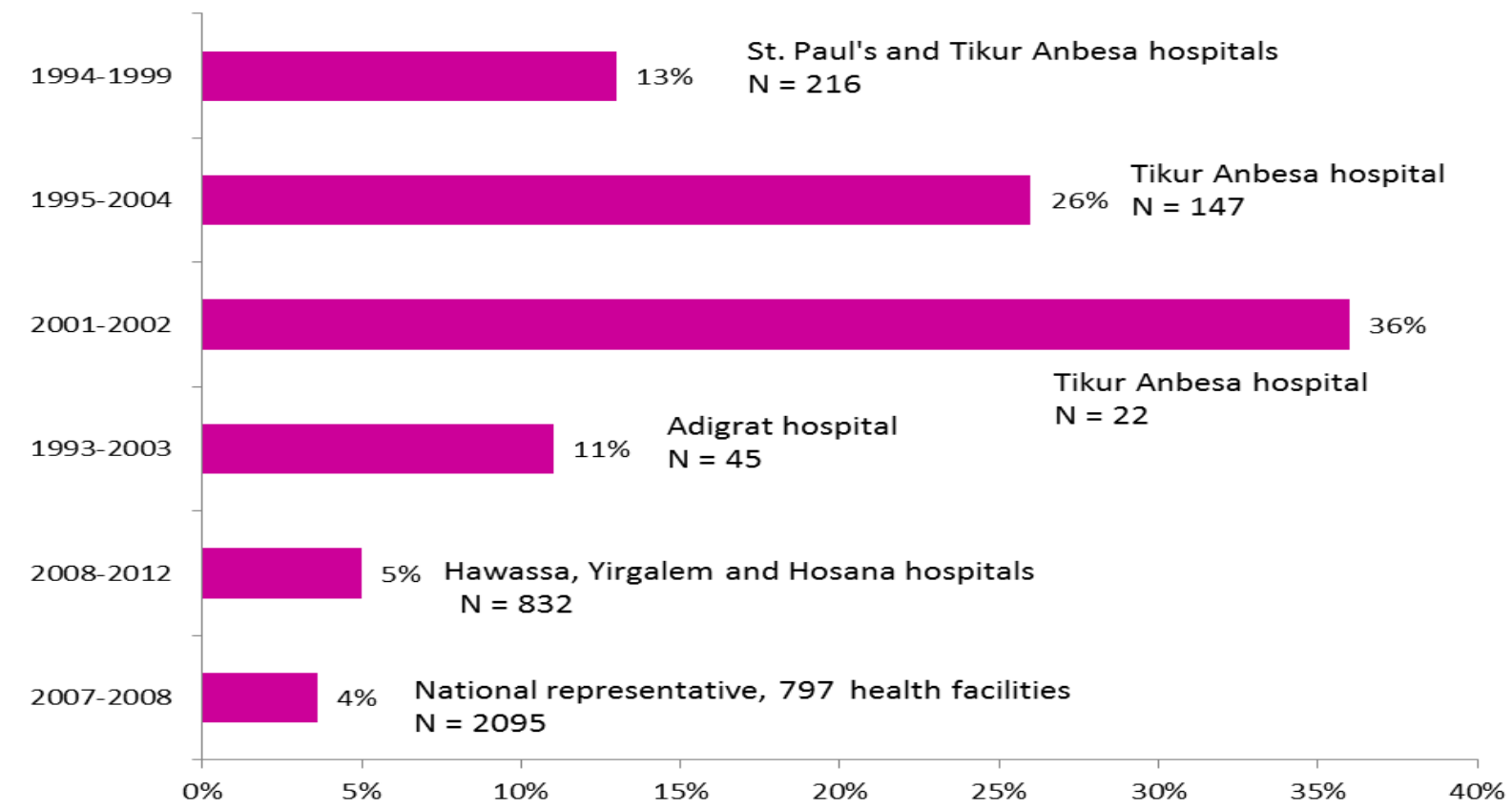

Figure 5: The case fatality rate of hypertensive disorders of pregnancy in Ethiopia between 1980 and 2012 (health facility based studies) $(19,21,23,28,30,31)$

With regard to maternal deaths due to hemorrhage (Figure 6), four studies $(13,16,17,21)$ reported $7 \%-10 \%$ while six studies $(15,20,26,27,29,31)$ reported $12 \%-28 \%$. The overall trend of maternal deaths due to hemorrhage seems increasing. However, because of several limitations among included studies and the lack of $95 \%$ confidence interval in the primary data, the observed difference in proportion of maternal mortality among different studies may not give conclusive evidence. The national representative study (26) and the other two relatively large scale studies (20, 27) showed that the proportion of maternal mortality due to hemorrhage was roughly in the range of $12 \%-20 \%$. The case fatality rate of hemorrhage in the national study (26) was $2 \%$.

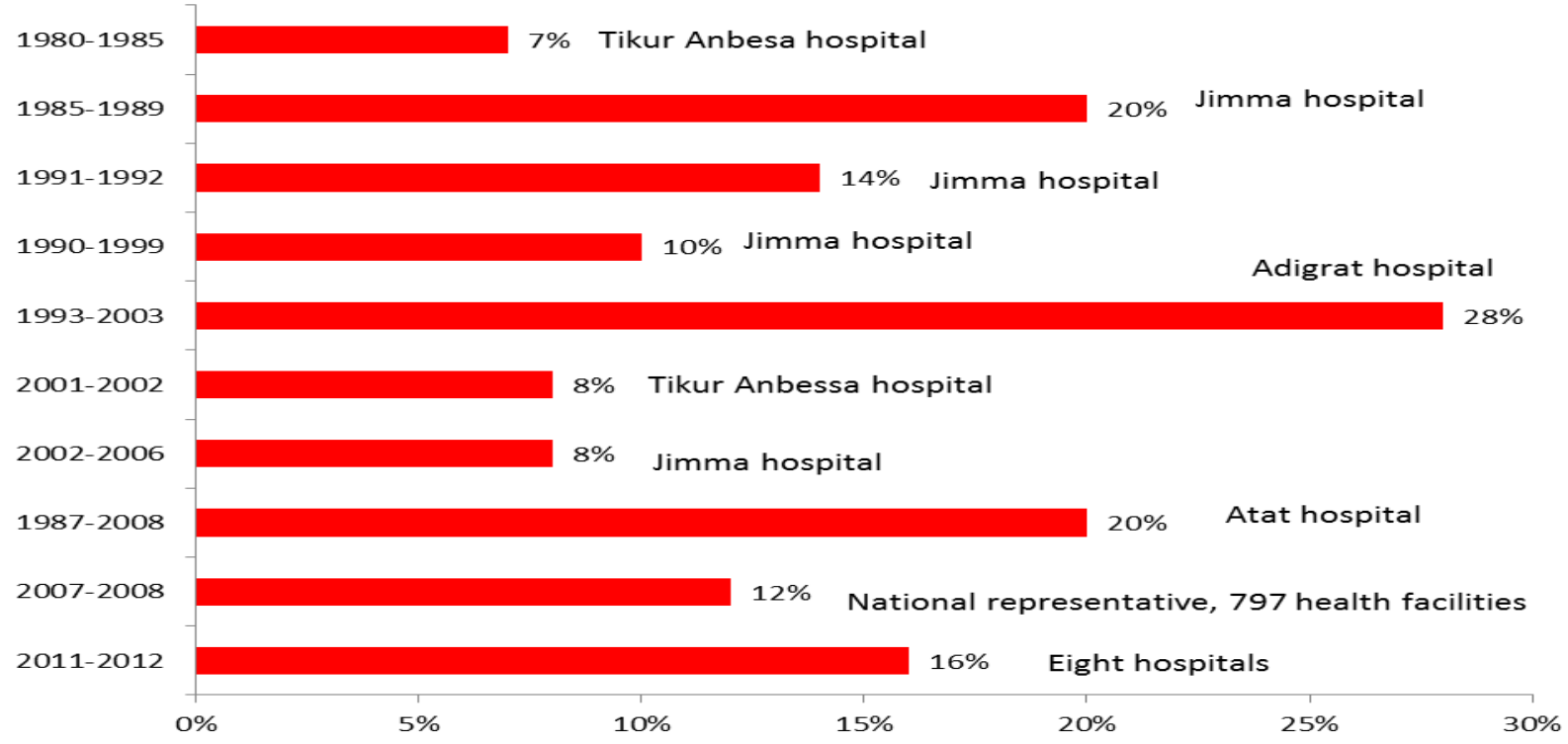

Figure 6: The proportion of maternal mortality due to hemorrhage (health facility based studies) $(15,17,18,22,23$, $26,28,29,31)$ 
As presented in Figure 7, infection was one of the major contributors for the high maternal mortality in Ethiopia in the 1980s-1990s and early 2000s. Particularly, the reports from Jimma and Ambo hospitals showed that more than a quarter of maternal deaths were due to infection. Among single hospital-based studies, relatively low proportion of maternal deaths due to infection was reported from Atat Hospital (20). Similarly, the national study (26) revealed that the proportion of infection related maternal mortality was the lowest among the top five causes of maternal mortality reviewed above (obstructed labor, HDP, hemorrhage, abortion and sepsis).

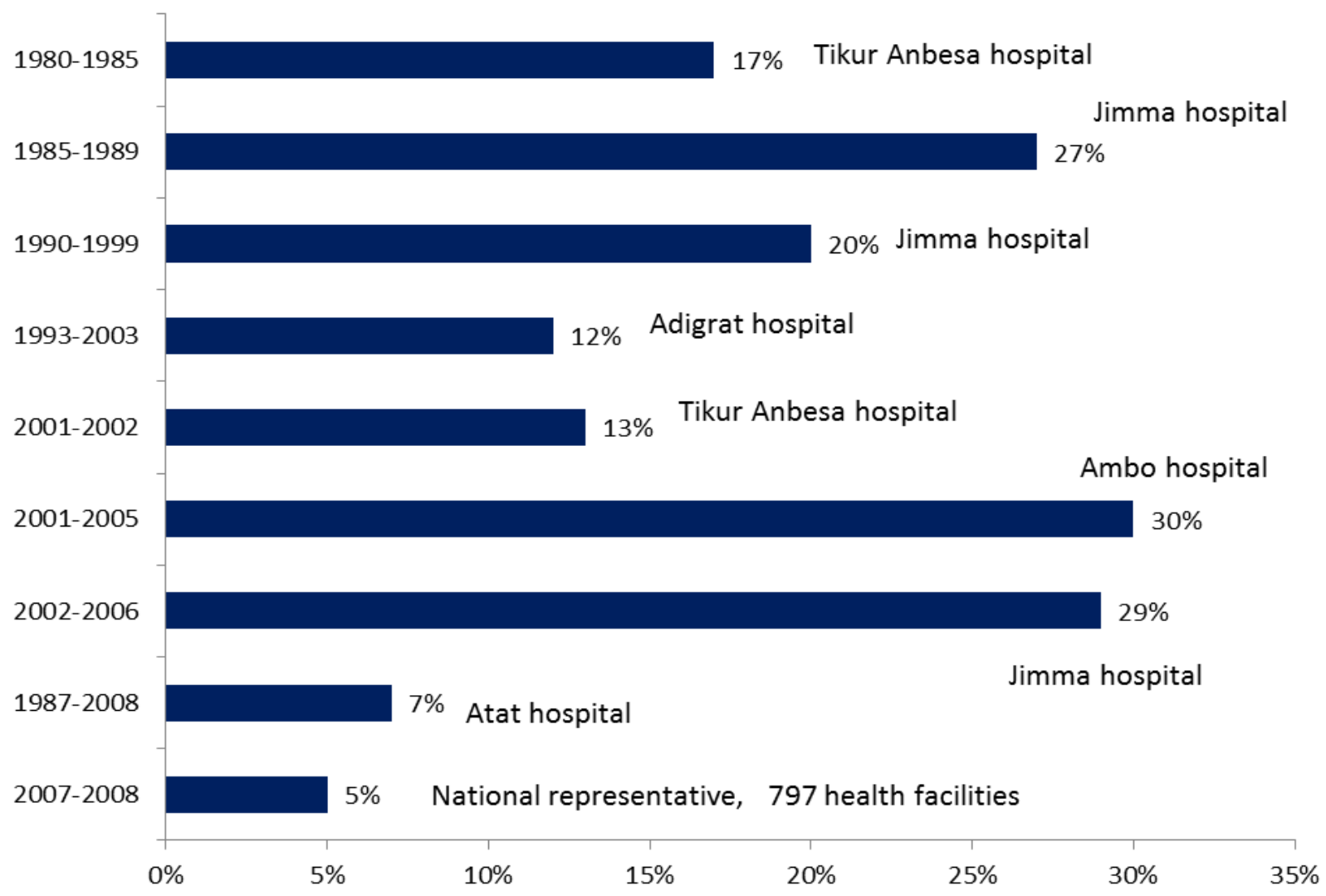

Figure 7: The proportion of maternal mortality due to puerperal sepsis (health facility based studies) (15, $18,22-24,26,29,31)$

Figure 8 summarizes the direct causes of maternal mortality before and after year the 2000 in Ethiopia $(13,15,20-22,24,26,27)$. The summary of findings from studies done between 1980 and 1999 showed that the top four causes of maternal mortality were abortion related complications $(31 \%)$, obstructed labor/uterine rupture $(29 \%)$, sepsis/infection (21\%) and hemorrhage (12\%). In the last decade, however, the top four causes of maternal mortality were obstructed labor/uterine rupture $(36 \%)$, hemorrhage (22\%), hypertensive disorders of pregnancy (19\%) and sepsis/infection $(13 \%)$.
In short, there has been a significant drop in the proportion of maternal mortality due to abortion and infection in the year 2000 and beyond. The maternal deaths due to obstructed labor/uterine rupture remained to be the leading cause. Hemorrhage and hypertensive disorders became the second and the third commonest causes of maternal deaths in the year 2000 and beyond. 
- Hemorrhage

- Hypertensive disorders

- Unsafe abortion
- Obstructed labor/uterine rupture

- Sepsis /Infection

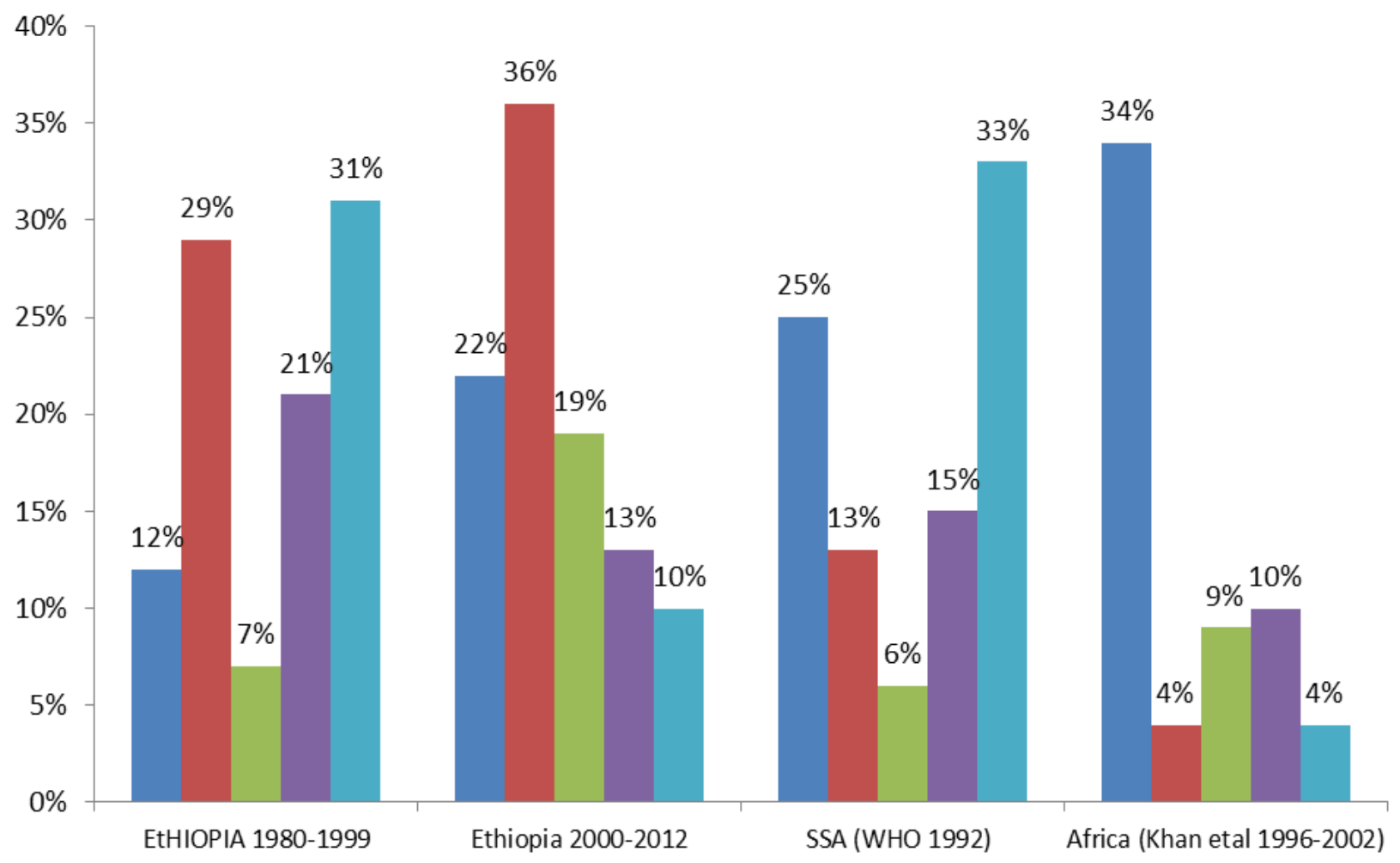

SSA = Sub Saharan Africa

Figure 8: Comparison of the causes of maternal mortality in Ethiopia in the 1980-1999 and 2000+ with 1992 and 1996-2002 WHO report for Sub-Saharan Africa (SSA) and Africa, respectively (15, 17, 18, 22-24, $26,28,33,34,35$ )

\section{DISCUSSION}

This review has shown that maternal mortality related to abortion has declined by more than three-fold in the past 30 years. An increasing trend of maternal mortality due to obstructed labor, hypertensive disorders and hemorrhage was observed in the same period.

In other words, in the 1980s and 1990s, the major cause of maternal deaths was complication of abortion. In 1981-1983, Kwast BE et al (32) also found that the leading cause of maternal mortality in Addis Ababa in the community and health facility settings was abortion (54\%). However, in the last decade, a significant drop in abortion related maternal mortality in the health facilities was observed. The Sedgh G et al (33) and WHO analysis by Khan KS et al (34) also found that, currently, less than $4 \%$ of women die from unsafe abortion in health facilities.

This is also the observation of the authors of this review in the last two decades. In the 1990s, in the majority of the public hospitals, there were 5-10 hospital beds which were reserved only for patients with abortion related complications. In the last decade, it was very unusual to encounter a patient with abortion complications that required inpatient treatment. In short, although there were several variations in the included studies' setting and design, we concluded that abortion related maternal deaths have been in sharp decline.

We speculate that the probable reasons for the significant decline in maternal mortality due to abortion complications in Ethiopia are: 
improvement in access to safe abortion and post abortion care; the liberal nature of the new abortion law (35), the ongoing in-service training on postabortal care, the increased public awareness about safe abortion and the increased number of private health facilities that provide safe abortion.

On the other hand, the continuity of high maternal mortality due to obstructed labor with or without uterine rupture, hemorrhage and hypertensive disorders may be explained by the fact that the majority of the pregnant women came to health facility very late and usually with advanced complications (11, 12, 22, 36, 37). Ethiopian demographic and health surveys had also showed that the majority of pregnant women had no antenatal care and 95\% in the 1995-2000 and $90 \%$ in the 2006-2011 gave birth at home unattended by skilled health personnel $(38,39)$. It was also pointed out that for postpartum hemorrhage, there are only two hours in which to intervene to prevent maternal death. Death from a ruptured uterus may take one day, and from eclampsia two days $(40,41)$. This implies that several of the women who died in the health facility probably came very late with fatal complications or the health facilities were incapacitated to provide timely lifesaving interventions.

The use of a less effective anticonvulsant drug (diazepam) (42) till about two years back in Ethiopia has probably contributed much to the increasing maternal mortality trend due to hypertensive disorders. The unpublished study from three public hospitals also indicated that the risk of convulsion recurrence was by five-fold less among eclamptic women treated with magnesium sulphate than those treated with diazepam (29), which is consistent with two Cochrane reviews $(42,43)$. Whether the increased maternal mortality due to hypertensive disorders in Ethiopia is also associated with increasing cardiovascular diseases due to change in lifestyle needs further investigation. Otherwise, with wide use of magnesium sulphate as anticonvulsant, there is a big hope that hospital based maternal mortality due to hypertensive disorders will be significantly declining in Ethiopia in the years to come.

The biggest challenge in the last three decades and perhaps in the years to come is obstructed labor and its complications. Several individual studies in
Sub Saharan Africa (44-47) and the WHO systematic review for Africa (34) showed that obstructed labor with or without uterine rupture accounted for less than 5\% of maternal mortality, which was more than two-fold less than the Ethiopian figure in the national study (13\%) and more than six-fold less than the finding of this review for the year 2000-2012 (36\%). This shows that the maternal mortality due to obstructed labor was unacceptably high in Ethiopia; and it was probably the reflection of the high prevalence of home delivery, especially in the rural areas (39). As presented in another article (48), although more than half of African countries achieved 50\%$99 \%$ health facility delivery, it was only $10 \%$ of women in Ethiopia who gave birth in health facility. Because of the deep rooted tradition of delivery practice at home, it is a day to day experience that the majority of pregnant women in Ethiopia stay at home laboring for 2-3 days and come to health facility when they are seriously ill.

In the old times, other African countries used to have relatively high maternal mortality due to obstructed labor with or without uterine rupture (49-52). We surmise that the change occurred in the last decade due to the improvement in skilled health personnel attended delivery rate. The authors of this review are also confident that similar changes in obstructed labor related maternal mortality will come in the coming decade if the current universal primary education, infrastructure and human resource development continue to scale up as discussed in another article. This is because; from the experience of high-income countries and from observation of pregnant women in urban areas in Ethiopia, obstructed labor related maternal mortalities are preventable.

With regard to obstetric hemorrhage related maternal mortality, this review showed somehow increasing trend (Figure 8). But, still it was not as high as the WHO estimate for Africa (34); and several other individual studies also reported that obstetric hemorrhage as the leading cause of maternal mortality in African, ranging from $26 \%$ $46 \%$ (50, 53-55). The findings of the individual studies from Ethiopia and this review, however, have to be interpreted very cautiously. Firstly, several women who died due to obstetric hemorrhage were probably under-reported. Secondly, some mothers who die of hemorrhage 
might be reported as a case of uterine rupture or hypertensive disorders.

The more than one-third reduction in maternal mortality due to infection in Ethiopia in the last decade was consistent with the WHO estimate for Africa (34). The use of potent and broad spectrum antibiotics could have contributed to the reduction of maternal deaths due to infection. However, there still is a possibility of categorizing infection related maternal deaths as obstructed labor or uterine rupture, which may be the underlying problem for the occurrence of infection.

Generally, when the data from Ethiopia for the year 1980-1999 is compared with the WHO report (56) for Sub Saharan Africa in 1992, the proportion of maternal deaths due to abortion (31\% vs 33\%) and hypertensive disorders (7\% vs $6 \%$ ) were almost consistent. However, there were more than double difference in the proportion of maternal deaths due to hemorrhage ( $12 \%$ vs $25 \%$ ) and obstructed labor with or without uterine rupture (29\% vs $13 \%)$.

The WHO analysis of causes of maternal deaths in Africa by Khan KS et al (34) for the 1996-2002 appears comparable with the data from Ethiopian for the year 2000-2012 with 95\% confidence interval, with the exception of obstructed labor: hemorrhage 34\% (13\%-44\%), obstructed labor $4 \%$ (0.0-10\%), hypertensive disorders $9 \%(2 \%-34 \%)$, sepsis/infection $10 \%$ $(10 \%-13 \%)$ and abortion $4 \%(0.0-24 \%)$. In short, obstructed labor with or without uterine rupture accounted for more than three-fold of maternal deaths in Ethiopia than the estimate for the whole Africa.

This review has limitations. Since the settings for the majority of the hospital-based studies were quite different, it is difficult to draw conclusions in reference to the nation. Above all, because of under-reporting, even in the hospital setting and the retrospective nature of the majority of the studies, the proportion of maternal mortality attributed to one type of direct cause may not reflect the actual magnitude of the problem.

In conclusion, this review identified some success story of reduced abortion and infection related maternal mortality. However, obstructed labor, hemorrhage and hypertension related maternal mortality were increasingly high. From literature $(40,41)$, these fatal obstetric complications are the result of lack of or delay in getting obstetric services. Since obstructed labor, hemorrhage and hypertension are identified as major causes of maternal mortality in health facilities, the focus should be on helping the mothers who appear at the health facility early.

\section{ACKNOWLEDGEMENT}

We would like to thank PANE and KMG Ethiopia for the modest financial support granted for this review. We are also grateful to UNFPA Ethiopia for their generous financial support to cover the publication fee.

\section{REFERENCES}

1. WHO, UNICEF, UNFPA and The World Bank joint estimates. Trends in Maternal Mortality: 1990 to 2010. Retrieved from: http://whqlibdoc.who.int

2. Hill $\mathrm{K}$, Thomas $\mathrm{K}$, AbouZahr $\mathrm{C}$ et al. Estimates of maternal mortality worldwide between 1990 and 2005: an assessment of available data. Lancet 2007; 370(9595), 13111319.

3. AbouZahr C. Maternal mortality. In: Murray CJL, Lopez AD. Health dimensions of sex and reproduction: the global burden diseases and injuries series. Harvard School of Public Health and World Bank 1998; 111 - 159.

4. WHO. The Mother-Baby Package: Implementing Safe Motherhood in Countries. Geneva: WHO, 1994.

5. World Health Organization (WHO), United Nations Populations Fund (UNFPA) and World Bank joint statement: Reduction of maternal mortality, 1999.

6. Bates I, Chapotera G, McKew S, van den Broek N. Maternal mortality in sub-Saharan Africa: the contribution of ineffective blood transfusion services. BJOG 2008; 115: 13311339.

7. Oyieke JB, Obore S, Kigondu CS. Millennium development goal 5: a review of maternal mortality at the Kenyatta National Hospital, Nairobi. East AfrMed J 2006; 83(1):4-9.

8. Alvarez JL, Gil R, Hernández V, Gil A. Factors associated with maternal mortality in Sub-Saharan Africa: an ecological study. 
BMC Public Health 2009; 9:462 doi: 10.1186/1471-2458-9-462.

9. Li XF, Fortney JA, Koltelchuck M, Glover LH. The postpartum period: the key to maternal mortality. Int J Gynaecol Obstet 1996; 54:1-10.

10. World Health Organization, "Revised 1990 Estimates of Maternal Mortality: A New Approach by World Health Organization (WHO) and United Nations Children's Fund (UNICEF)". World Health Organization, Geneva, April 1996, WHO/FRH/MSM/96.11.

11. Abdella A. Maternal Mortality Trend in Ethiopia J Health Dev 2010; 24 (Special Issue 1):115-122.

12. Gaym A. Maternal mortality studies in Ethiopia-magnitude, causes and trends. Ethiop Med J 2009; 47(2): 95-108.

13. Yoseph S, Kifle G. A six year review of maternal mortality in a teaching hospital in Addis Ababa. Ethiop Med J 1988; 26:115119.

14. Yusuf L, Zein ZA. Abortion at Gondar college hospital, Ethiopia. East Afr Med J 2001; 78(5): 265-268.

15. Ali Y. Analysis of maternal deaths in Jimma Hospital, Southwestern Ethiopia. Ethiop Med J 1994; 32(2):125-29.

16. Gaym A. A review of maternal mortality at Jimma hospital, South West Ethiopia. Ethiop J Health Dev 2000; 14(2):215-223.

17. Abate M, Lakew Z. Eclampsia a 5 years retrospective review of 216 cases managed in two teaching hospitals in Addis Ababa. Ethiop Med J 2006; 44(1): 27-31.

18. Gessessew A, Mesfin M. Obstructed labor in Adigrat zonal hospital, Tigray region, Ethiopia. Ethiop J Health Dev 2003; 17(3): 175-180.

19. Eyob Berihun E, Gaym A. Risk factors for mortality among eclamptics admitted to the surgical intensive care unit at Tikur Anbessa Hospital, Addis Ababa, Ethiopia. Ethiop $J$ Repr Health 2007; 1(1):4-16.

20. Kelly J, Kohls E, Poovan P, et al. The role of a maternity waiting area (MWA) in reducing maternal mortality and stillbirths in high-risk women in rural Ethiopia. BJOG 2010; 117: 1377-1383.

21. Berhan Y, Abdella A. Emergency obstetrics performance with emphasis on operative delivery outcome: Does it reflect the quality of care. Ethiop J Health Dev 2004; 18(2):96-106.

22. Garomsa H, Dwivedi AD. Maternal mortality in Ambo hospital: A five year retrospective review. Ethiop J Reprod Health 2008; 2: 2-13.

23. Gessessew A. Abortion and Unwanted Pregnancy in Adigrat Zonal Hospital, Tigray, North Ethiopia. Afr J Reprod Health 2010; 14(3): 183-188.

24. Negussie D, Mesfin N. Review of maternal death in Jimma University specialized hospital. Ethiop J Health Sci 2009; 19(1): 912.

25. Gebreselassie H, Fetters $\mathrm{T}$, Singh $\mathrm{S}$, et al. Caring for Women with Abortion Complications In Ethiopia: National Estimates and Future Implications. Int Perspect Sex Reprod Health 2010; 36(1):6-15.

26. Federal Ministry of Health of Ethiopia, UNICEF, UNFPA, WHO, AMDD. National baseline assessment for emergency obstetric and newborn care. Ethiopia 2008.

27. FIGO. Maternal Death and Near Miss Reviews in eight hospitals in Ethiopia. Last accessed in August 2013. http://www.figo.org/projects/maternal-andnewborn-health/ethiopia

28. Endeshaw G, Berhan Y. Predictors of maternal mortality in women with hypertensive disorders of pregnancy: A retrospective cohort study in three teaching hospitals (Unpublished study).

29. Gessessew A. Maternal complications - in a zonal hospital. Ethiop Med J 2007; 45(1):4754.

30. Mekbib T, Gebrehiwot Y, Fantahun M. Survey of unsafe abortion in selected health facilities in Ethiopia. Ethiop J Reprod Health, 2007, 1(1):28-43. http://www.esog.org.et

31. Ghidey E, Assefa M, Mohammed S, Tessema F. Analysis of deliveries at Jimma hospital: a four years retrospective study. Eth $J$ Health Dev 1991;5(1):3-6.

32. Kwast BE, Rochat RW, Kidane-Mariam W. Maternal Mortality in Addis Ababa, Ethiopia. Stud Fam Plann 1986; 17(6):288-301.

33. Sedgh G, Henshaw S, Singh S, Ahman $\mathrm{E}$, Shah IH. Induced abortion: estimated rates and trends worldwide. Lancet 2007; 370(9595):1338-1345. 
34. Khan KS, Wojdyla D, Say L, Gülmezoglu AM, Van Look PFA. WHO analysis of causes of maternal death: a systematic review. Lancet 2006; 367: 1066-74

35. Federal Democratic Republic of Ethiopia. The new Criminal Code Article 552. 2004.

36. Thaddeus S, Maine D. Too far to walk: maternal mortality in context. Soc Sci Med 1994; 38: 1091-1110.

37. Babinard J, Roberts P. Maternal and child mortality development goals: what can the transport sector do? World Bank, 2006. Retrieved from http://www.eldis.org/

38. Central Statistical Agency [Ethiopia] and ICF International. 2001. Ethiopia Demographic and Health Survey 2000. Addis Ababa, Ethiopia and Calverton, Maryland, USA: Central Statistical Agency and ICF International.

39. Central Statistical Agency [Ethiopia] and ICF International. 2012. Ethiopia Demographic and Health Survey 2011. Addis Ababa, Ethiopia and Calverton, Maryland, USA: Central Statistical Agency and ICF International.

40. Monitoring Emergency Obstetric care: A handbook. World Health Organization, 2009. Retrieved at: http://www.unfpa.org/

41. Abe E, Omo-Aghoja LO. Maternal mortality at the Central Hospital, Benin City Nigeria: a ten year review. Afr J Reprod Health 2008; 12(3):17-26.

42. Duley L, Henderson-Smart DJ, Walker GJ, Chou D. Magnesium sulphate versus diazepam for eclampsia. Cochrane Database Syst Rev 2010; (12):CD000127. doi: 10.1002/14651858.CD000127.Pub2.

43. Duley L, Henderson-Smart D. Magnesium sulphate versus diazepam for eclampsia. Cochrane Database Syst Rev 2003; (4):CD000127. Pub1.

44. Lema VM, Changole J, Kanyighe C, Malunga EV. Maternal mortality at the Queen Elizabeth Central Teaching Hospital, Blantyre, Malawi. East Afr Med J 2005; 82(1):3-9.

45. Rutgers S. Two years maternal mortality in Matebeleland north Province, Zimbabwe. Cent Afr J Med 2001; 47(2):39-43.

46. Murthy BK, Murthy MB, Prabhu PM. Maternal Mortality in a Tertiary Care
Hospital: A 10-year Review. Int J Prev Med 2013; 4(1): 105-109.

47. Elhassan M Elhassan, Omer A Mirghani, Ishag Adam. High maternal mortality and stillbirth in the Wad Medani Hospital, Central Sudan, 2003-2007. Trop Doct 2009; 39 (4): 238-39.DOI: 10.1258/td.2009.090005

48. Berhan Y, Berhan A. Skilled health personnel attended delivery as a proxy indicator for maternal and perinatal mortality: A systematic review. Ethiop J Health Sci 2014; Special issue 1

49. Juma EA, Odiyo FN. Maternal mortality occurring at the Rift Valley Provincial General Hospital, Nakuru. East Afr Med J 2001; 77(7):382-5.

50. Bouvier-Colle MH, Ouedraogo C, Dumont A, Vangeenderhuysen C, Salanave B, Decam C. Maternal mortality in West Africa. Rates, causes and substandard care from a prospective survey. Acta Obstet Gynecol Scand 2001; 80(2):113-9.

51. Vork FC, Kyanamina S, van Roosmalen J. Maternal mortality in rural Zambia. Acta Obstet Gynecol Scand 1997; 76(7):646-50.

52. Prual A, Bouvier-Colle MH, de Bernis L, Bréart G. Severe maternal morbidity from direct obstetric causes in West Africa: incidence and case fatality rates. Bull World Health Organ 2000; 78(5):593-602.

53. Ronsmans C, Graham WJ. Maternal Survival Series steering group Maternal mortality: who, when, where, and why. Lancet 2006; 368: 1189- 2000.

54. Martey JO, Djan JO, Twum S, Browne EN, Opoku SA. Maternal mortality and related factors in Ejisu District, Ghana. East Afr Med $J$ 1994; 71(10):656-60.

55. Kongnyuy EJ, Mlava G, van den Broek N. Facility-based maternal death review in three districts in the central region of Malawi: an analysis of causes and characteristics of maternal deaths. Women's Health Issues 2009; 19(1):14-20.

56. WHO (World Health Organization). 1992. International Statistical Classification of Diseases and Related Health Problems. 